International Journal of Oceans and Oceanography

ISSN 0973-2667 Volume 14, Number 1 (2020), pp. 17-32

(C) Research India Publications

https://dx.doi.org/10.37622/IJoo/14.1.2020.17-32

\title{
Analysis of Bajomulyo Coastal Fishing Harbor Development in Pati Regency, Central Java, Indonesia
}

\author{
Rofik Muammar $^{1}$, Herry Boesono ${ }^{2}$ and Pujiono Wahyu Purnomo \\ ${ }^{1}$ Coastal Resource Management Study Program, Faculty of Fishery and Marine \\ Affairs, Universitas Diponegoro \\ ${ }^{2}$ Capture Fisheries Department, Faculty of Fishery and Marine Affairs, \\ Universitas Diponegoro \\ Universitas Diponegoro, Faculty of Fishery and Marine Affairs, \\ Jalan Prof. Soedarto, SH Tembalang Semarang Indonesia 50275
}

\begin{abstract}
This study aims to develop an appropriate development strategy so that the Bajomulyo Coastal Fishing Harbor (PPP) in Pati Regency can contribute maximally in supporting capture fisheries activities. The analytical method used was a combination of SWOT and QSPM. Respondents consisted of the Head of the Maritime Affairs and Fisheries Office of Central Java Province, the Head of the Bajomulyo Coastal Fishing Harbor Pati, the Head of the Management of Fish Auction (TPI), the Syahbandar of Fisheries, and the Head of Fish Auction II Bajomulyo. The results of this study indicate that the internal and external position of the Bajomulyo Coastal Fishing Harbor development strategy was in quadrant I (Strength - Opportunity), namely by utilizing all the strengths and opportunities as much as possible, as well as minimizing threats and weaknesses in the Bajomulyo Coastal Fishing Harbor development effort. Alternative strategies for developing Bajomulyo Coastal Fishing Harbor in Pati Regency based on the order of the five main priorities are (1) the implementation of the mandate of Law 23/2014 on regional government (7.536); (2) stipulation of Fishery Port Operational Work Area (WKOPP) and local regulation on Coastal Fishing Harbor management (7.487); (3) optimizing the implementation of
\end{abstract}


Coastal Fishing Harbor functions and performance (7.182); (4) addition of managerial HR, Training for Coastal Fishing Harbor management in the context of improving services to Coastal Fishing Harbor functions and facilities and adding basic facilities (7.003); and (5) fostering good relations with local governments, investors and relevant stakeholders to support integrated fisheries port management (6.845).

Keywords: Bajomulyo, Fishery Port, Development, Management, QSPM, SWOT.

\section{INTRODUCTION}

Pati is a coastal Regency where coastal communities rely heavily on fishing businesses, both as fishermen, fish cultivators, fish processors, fish trade and businesses that support fisheries businesses, such as transportation, credit, trade-in fishing equipment, ice factories, culinary and fuel supply. In Pati Regency's economy, fisheries are part of the agriculture, forestry and fisheries sectors. The contribution of agriculture, forestry and fisheries is relatively large, namely above $20 \%$, but the growth is small ${ }^{[1]}$.

Pati Regency has several Fish Auctions, including Bajomulyo I Fish Auction, Bajomulyo II Fish Auction, Pecangan Fish Auction, Margomulyo Fish Auction, Sambiroto Fish Auction, Alas Dowo Fish Auction, Banyutowo Fish Auction and Puncel Fish Auction. The biggest catch fishery product in Pati Regency was dominated by Fish Auction Bajomulyo Unit I and Fish Auction Bajomulyo Unit II. The fishing gear that was widely operated in Fish Auction Bajomulyo Unit I was cantrang and squid nets. Whereas at Fish Auction Bajomulyo Unit II, the fishing gear that was mostly used by fishermen is purse seine. Bajomulyo Coastal Fishing Harbor was the largest fishing base in Pati Regency. Ships used above 30 GT and fishing gear used include purse seines, squid nets and cantrang ${ }^{[1]}$.

To carry out the Bajomulyo Pati Coastal Fishing Harbor management authority, the Government of Central Java Province has established a Technical Implementation Unit (UPT), namely: UPT Bajomulyo Pati Fisheries Port - Central Java Provincial Maritime and Fisheries Service, following Central Java Governor Regulation No. 38 of 2008 concerning Organization and Work Procedure of the Technical Implementation Unit at the Office of Maritime Affairs and Fisheries in Central Java Province ${ }^{[2]}$.

From 816 fishing ports in Indonesia, there are still around $70 \%$ of fishing ports that are not yet functioning optimally. In terms of completeness of facilities, most still need to be improved. The low quality of human resources of managers and users is also one of the factors that make fisheries port management not yet optimal ${ }^{[3]}$. The complexity of the problems within the scope of capture fisheries also contributes to the weak management of fishing ports ${ }^{[4][5]}$. 
Not yet optimal management of fishing ports is also commonly found in fisheries port research, namely because of the incompatibility between existing facilities and the provisions in the regulations. This is reinforced by the results of the facility user satisfaction index that is not good because fisheries port management is not yet optimal ${ }^{[6]}$. In general, fisheries port development activities still need to be carried out, because fishing port management is still not optimal ${ }^{[7][8]}$.

For the Bajomulyo Coastal Fishing Harbor fishing port, the condition of functional facilities is now quite complete, but some facilities are still poorly maintained and require repairs ${ }^{[9]}$. The hygienic index in the two Fish Auctions in the Bajomulyo Coastal Fishing Harbor still does not meet the hygienic port requirements. To be hygienic, it is necessary to develop port facilities including basic and functional facilities ${ }^{[10]}$. Bajomulyo Coastal Fishing Harbor itself has a positive perception value from the surrounding community, mainly based on the economic and social impacts in the form of an increase in community income and as a driver of the economy, as well as absorbing labour ${ }^{[11]}$.

The implementation of the Bajomulyo Coastal Fishing Harbor fishing port has not yet fully gone well. This can be seen from the absence of working areas and operating areas for fishing ports (WKOPP), as well as regional regulations governing management authority, as stipulated in the Regulation of the Minister of Maritime Affairs and Fisheries of the Republic of Indonesia Number 8 of 2012 concerning Fisheries Ports. Bajomulyo Coastal Fishing Harbor fishing port is located in the Regency government area, but the management authority is owned by the provincial government, as stipulated in Law Number 23 of 2014 concerning Regional Government and Central Java Governor Regulation No. 38 of 2008 concerning Organization and Work Procedures of Technical Implementation Units at the Office of Maritime Affairs and Fisheries of Central Java Province. This has led to a conflict of authority in the management of the Bajomulyo Coastal Fishing Harbor. The conflict is related to the acquisition of Original Local Revenue (PAD) so that it has an impact on the less optimal management of Bajomulyo Coastal Fishing Harbor. The right policy is needed so that the continuation of the authority over the management of the fishery port, in the management process, problems do not appear ${ }^{[12]}$.

In accordance with its main tasks and functions, the presence of the Bajomulyo Pati Coastal Fishing Harbor is expected to take part in improving fishing services, from preproduction, production to post-production. The final goal to be achieved is the development of Bajomulyo Coastal Fishing Harbor Pati through optimizing its strengths and opportunities, while simultaneously minimizing its weaknesses and threats. Thus we can see the factors of power, weakness, opportunities, and threats that the port has so that the Bajomulyo Coastal Fishing Harbor development strategy can be developed so that it can develop better. 


\section{MATERIAL AND METHODS}

\subsection{Location and Time of Research}

The locations of this study were at Bajomulyo Coastal Fishing Harbor in Pati Regency, Central Java, Indonesia (Figure $1^{[13]}$ ). This research was conducted in May-September 2019.

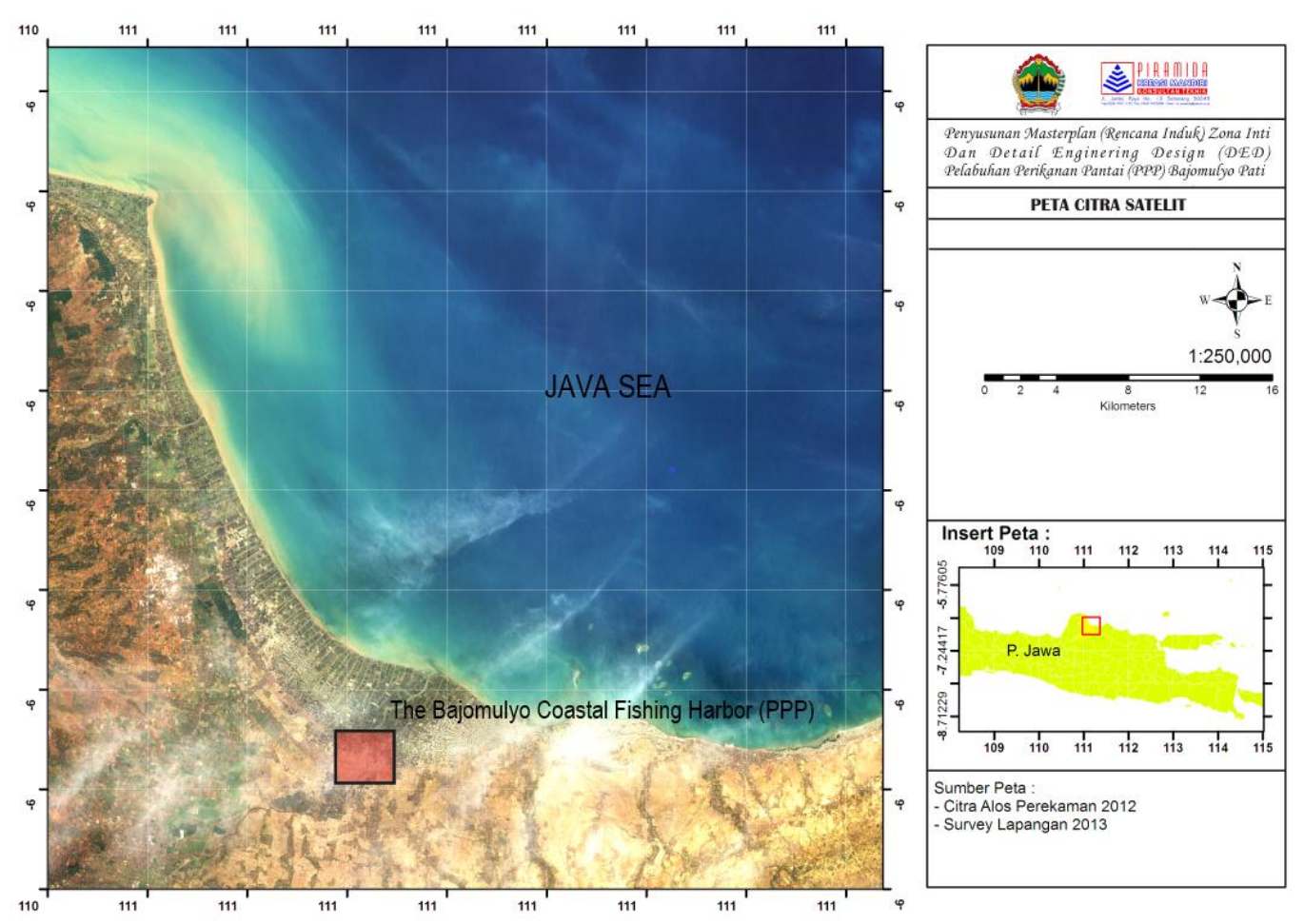

Figure 1. Map of The Bajomulyo Coastal Fishing Harbor ${ }^{[13]}$

\subsection{Methods}

The type of data used in this study was primary data, obtained from the results of interviews with respondents. Primary data taken was data related to the management of Bajomulyo Coastal Fishing Harbor, including data related to the potential which was the strength of the organization, weaknesses, threats faced by the organization, and opportunities that can be developed from the organization. The sampling method used was purposive sampling, which was done by taking data from selected people according to the criteria of the researcher. The criteria determined by the researcher were the key respondents who were related to the management of Fish Auction. The respondents included (1) Head of Bajomulyo Coastal Fishing Harbor Pati, (2) Head of Maritime Affairs and Fisheries Service in Pati Regency, (3) Head of Operational and Martyrdom Administration Section, (4) Fishery Syahbandar, (5) Head of Fish Auction II Bajomulyo, and (5) fishing port expert. 


\subsection{Analysis}

The analytical method used was SWOT-QSPM, which is a combination of analysis of the QSPM (quantitative strategic planning management) and SWOT (Strengths, Weaknesses, Opportunities, Threats). This merger was carried out because SWOT analysis has many weaknesses, such as too qualitative if it is quantified and it is not clear what the weight is between the factors of each component ${ }^{[14]}$. QSPM is an analytical technique used to determine the relative attractiveness (attractiveness score) of various alternative actions so that it can objectively show the best strategy from various alternative strategies available. QSPM calculations were based on inputs from internal and external matrix weights, as well as alternative strategies at the matching stage $^{[15]}$.

\section{RESULTS AND DISCUSSION}

\subsection{Results}

The results in the identification of internal factors that are a strength factor of the Bajomulyo Coastal Fishing Harbor are as follows:

a. The large number of vessels that ship fish at Bajomulyo Coastal Fishing Harbor Bajomulyo Coastal Fishing Harbor data in 2018 recorded as many as 2894 ship visits, while the amount of fish production in 2018 Bajomulyo Coastal Fishing Harbor was 23,168.1 tons. Although the number of ship visits and the number of fish production has decreased in the last 3 years, the number was still relatively large and deserves to be categorized as a strength factor from Bajomulyo Coastal Fishing Harbor.

b. The availability of 2 Fish Auction units, namely Fish Auction Bajomulyo I and Fish Auction Bajomulyo II

Bajomulyo Coastal Fishing Harbor has 2 Fish Auction units, namely Fish Auction unit I which is an old Fish Auction Place that was built for the first time, then Fish Auction unit II which was only built next after Fish Auction unit I. Fish Auction 1 serves a fishing fleet under 30 Gross Tonnage (GT), with fishing gear in the form of cantrang nets (already banned), gill nets, mini purse seines, squid nets, and some traditional fishing gear such as shrimp nets, small crabs and anchovies. Fish Auction II serves a fishing fleet of more than 30 GT size with purse seine fishing gear.

c. A good relationship between Coastal Fishing Harbor and Coastal Fishing Harbor service users

The creation of a good relationship between the port service user and the port manager, as a place to carry out government functions and permit service for 
fishing vessel documents. This has become one of the internal strengths owned by the Bajomulyo Coastal Fishing Harbor.

d. Village unit economic cooperative (KUD) support

The fisherman KUD is a legal entity organization formed by fishermen whose function is to assist the interests of fishermen in meeting business needs, in the form of capital loans, ice supplies, and Solar Packed Fishing Dealer (SPDN) management. The Bajomulyo Coastal Fishing Harbor was supported by the Sarono Mino cooperative. This support has become one of the internal strengths owned by Bajomulyo Coastal Fishing Harbor.

e. Better catch quality (refrigerator fishing boats)

Purse seine was the dominant fishing gear in the Bajomulyo Coastal Fishing Harbor (Fish Auction 2), with 62\% of the total fishing gear used in the Bajomulyo Coastal Fishing Harbor. A total of 187 units of purse seine ships of which 97 vessels have been refrigerated, while the remaining 90 purse seine vessels are still ice-cold. Catch fish using refrigerator purse seine vessels have better quality than using ice-cooled purse seine vessels ${ }^{[16]}$.

The results of the identification of internal factors which are the weaknesses of the Bajomulyo Coastal Fishing Harbor are as follows:

a. Access in and out of the ship far, narrow, and shallow

Access to and from the Bajomulyo Coastal Fishing Harbor ship through the Silugonggo River, which is $5.8 \mathrm{~km}$ from the river mouth. The river is silting every year because of the material that is carried by the river and settles along the Silugonggo River. Ships with large GT sizes need scout boats to avoid running aground. A large number of ships moored along the river also makes the ship's traffic narrow. These three things are very disturbing activities in and out of the ship ${ }^{[17]}$.

b. There is no ministerial decree, regarding the Fishery Port Operational Work Area (WKOPP) of Bajomulyo Coastal Fishing Harbor

WKOPP is a mainland working area and a fishery harbor working area, as well as a fishery port and maritime operating area. The terrestrial work area includes the terrestrial area used for the construction and operational activities of basic, functional and supporting fishing port facilities, while the water working area covers the territorial waters used for shipping, port and other activities. The terrestrial operating area includes land that directly influences the development of a fishing port, while the water operating area includes an area that has a direct influence on the development of a fishing port. 
Until now the WKOPP of Bajomulyo Coastal Fishing Harbor determination is still in process. Supporting data already exists, but there is still a correction in the coordinates, the Pati regent's recommendation. The WKOPP has not been established yet as one of the obstacles in managing Bajomulyo Coastal Fishing Harbor.

c. Inadequate quantity and quality of HR managers

The number of Bajomulyo Coastal Fishing Harbor employees is 19 from the standard number of human resources which should be 24 people, consisting of 9 people as civil servants (PNS) and 10 people as contract workers (non-PNS). This amount is still lacking to manage the port with a total production of 23,168.1 tons per year. Out of 19 Bajomulyo Coastal Fishing Harbor employees, 5 of them were still in high school education, 2 of them were civil servants, and 3 were non-civil servants.

d. The area of Bajomulyo's Coastal Fishing Harbor is narrow

The land area owned by the Bajomulyo Coastal Fishing Harbor is currently around 4 hectares in 2 locations, namely Fish Auction Bajomulyo unit I around 0.88 hectares and Fish Auction Bajomulyo II around 3.2 hectares or all of which amount to 4 hectares. Based on the Minister of Maritime Affairs and Fisheries Regulation No. PER.8 / MEN / 2012 concerning Fisheries Port that the Coastal Fishing Harbor class has a minimum of 5 hectares of land, but in Bajomulyo Coastal Fishing Harbor only 4 hectares, so it can be said that the land in the Bajomulyo Coastal Fishing Harbor is narrow ${ }^{[18]}$. The results of observations, the land in the Fish Auction Bajomulyo units I and II have been fully built various facilities so that no further development can be done on the land unless there is additional land in another location.

e. The lack of basic/functional facilities in Coastal Fishing Harbor

Bajomulyo Coastal Fishing Harbor facilities were not yet complete. Facilities that have not yet been fulfilled by the Bajomulyo Coastal Fishing Harbor managers were Fisherman Fueling Stations (SPBN), clean water, ice factories, and ship docking. The existing mooring dock facilities and port ponds have also not been able to accommodate port activities due to the large size of GT ships and a large number of vessels landing fish in the Bajomulyo Coastal Fishing Harbor. It takes the construction of a mooring pier (supply pier), and a special port pond to serve ships entering the Bajomulyo Coastal Fishing Harbor. Some port facilities also need to be added to buildings and routine maintenance. Additional buildings are needed at Fish Auction Bajomulyo unit I and II unloading docks, namely the addition of a canopy from the end of the pier to the Fish Auction building so that landed fish are not exposed to direct sunlight or rain so that the quality of landed fish will be maintained. The silting up of the 
Silugonggo River needs to be done in the form of routine dredging so that the depth is always obtained appropriate for shipping lanes and port ponds ${ }^{[17]}$.

Internal factors (strengths and weaknesses) in the Bajomulyo Coastal Fishing Harbor development above were further analyzed using the IFE Matrix. The assessment of internal factors is based on the results of in-depth interviews and questionnaires from experts in the field, which are related to the management or development of the Bajomulyo Coastal Fishing Harbor fishing port. The assessment is presented in Table 1.

The results of the identification of external factors that become opportunity factors of the Bajomulyo Coastal Fishing Harbor are as follows:

a. The designation of Bajomulyo Coastal Fishing Harbor as one of the mina politan areas

Mina politan area was intended to increase fisheries production for the welfare of the community. The mina politan program was being rolled out as an accelerator for regional-based marine and fisheries development that was capable of generating a multiplier effect on the regional economy. The making of the Bajomulyo Coastal Fishing Harbor as one of the mina politan areas was an added value, as an opportunity from external factors.

b. Fish resources are still available

Based on the information, fishing vessels from Bajomulyo Coastal Fishing Harbor catch fish in Fisheries Management Area (WPP) 711, 712, 713, and 718. Purse seine vessels catch small pelagic fish in WPP 712, 713 and 718. Cantrang vessels catch demersal fish in WPP 712. Longline vessels catch small pelagic fish in WPP 712, 713, and 718. Cantrang vessels catch demersal fish in WPP 712. Longline vessels catch small pelagic fish in WPP 712, 713, and 718. Cantrang vessels catch demersal fish in WPP 712. Longline vessels catch large coral and pelagic fish in 711, 712 and 713. Gillnet vessels catch fish in WPP 712 and 718. Squid vessels capture squid in WPP 712. Based on this, the development of the Bajomulyo Coastal Fishing Harbor must pay attention to the level of utilization of each WPP above ${ }^{[17][19]}$.

c. Absorbing labour

With the development of the Bajomulyo Coastal Fishing Harbor and business opportunities for investors to invest, it is hoped that this will have a positive impact on the economy of the communities surrounding the port. The positive impact is the increase in business and the opening of new jobs.

d. Number of catch buyers (healthy auction price competition)

A large number of captured fish buyers with healthy auction price competition 
was one of the opportunities owned by Bajomulyo Coastal Fishing Harbor. With total production data of 23,168.1 tons per year, an average of 1,930,675 tons of fish caught is bought by buyers every month.

e. A large amount of private cold storage

In the Bajomulyo Coastal Fishing Harbor area, there was a lot of cold storage managed by the private sector. This can be an opportunity if it can be managed properly. Large capture fisheries production results can be handled well to maintain its quality.

The results of the identification of external factors that pose a threat factor from the Bajomulyo Coastal Fishing Harbor are as follows:

a. Mooring facilities are mostly managed by the community

Many mooring facilities managed by the community become one of the threats owned by the Bajomulyo Coastal Fishing Harbor. The implementation of port management regulations in the Bajomulyo Coastal Fishing Harbor has not yet been implemented, causing residents to collect money from ships that are anchored and anchored at the Bajomulyo Coastal Fishing Harbor dock.

b. The auction payment process has not been smooth (prone to the lack of payment for fish auction or KPLI)

There are still obstacles in paying in cash to fishermen due to delays in payments from collectors. This is vulnerable to the occurrence of the Fish Auction Payment Deficiency.

c. Development was hampered with Law 23/2014 concerning local government

The mandate of Law No. 23 of 2014 concerning local government so far has not been implemented in the Bajomulyo Coastal Fishing Harbor. This was because the Pati regional government has not yet surrendered the P3D assets to Central Java Province, so this problem has become one of the threat factors that hindered the development of the Bajomulyo Coastal Fishing Harbor.

d. Decreasing the number of fish landings from cantrang vessels

There are about 209 units of cantrang vessels in the Bajomulyo Coastal Fishing Harbor which were currently included in fishing gears which are prohibited from being operated by the government ${ }^{[20]}$. However, until March 2019 the cantrang fishing gear in the Bajomulyo Coastal Fishing Harbor was temporarily still operating at sea based on a letter from the Secretary-General of the Ministry of Maritime Affairs and Fisheries (KKP) Number 113 / SJ / II / 2018 concerning Instructions and Requirements for Issuance of Certificate of Sea (SKM) up to an undetermined deadline depends on the KKP's policy going forward. Nevertheless, the number of fish landings from cantrang vessels was decreasing. 
e. Number of cases of ship fire (too crowded)

Bajomulyo Beach Fishery Port does not have a special port pool so that ships mooring along the Silugonggo River irregularly. This raises several problems such as if the ship's movement was hampered, the potential for ship accident, and ship fire.

The external factors (opportunities and threats) in the Bajomulyo Coastal Fishing Harbor development above were further analyzed using the EFE Matrix. The assessment of internal factors was based on the results of in-depth interviews and questionnaires from experts in the field, which are related to the management or development of the Bajomulyo Coastal Fishing Harbor fishing port. The assessment was presented in Table 2 .

Based on the results of the IFE matrix analysis Table 1 and EFE Table 2 it can be seen that the internal and external positions of the Bajomulyo Coastal Fishing Harbor development strategy were in quadrant I $(3.07,2.88)$, which presented in Figure 2.

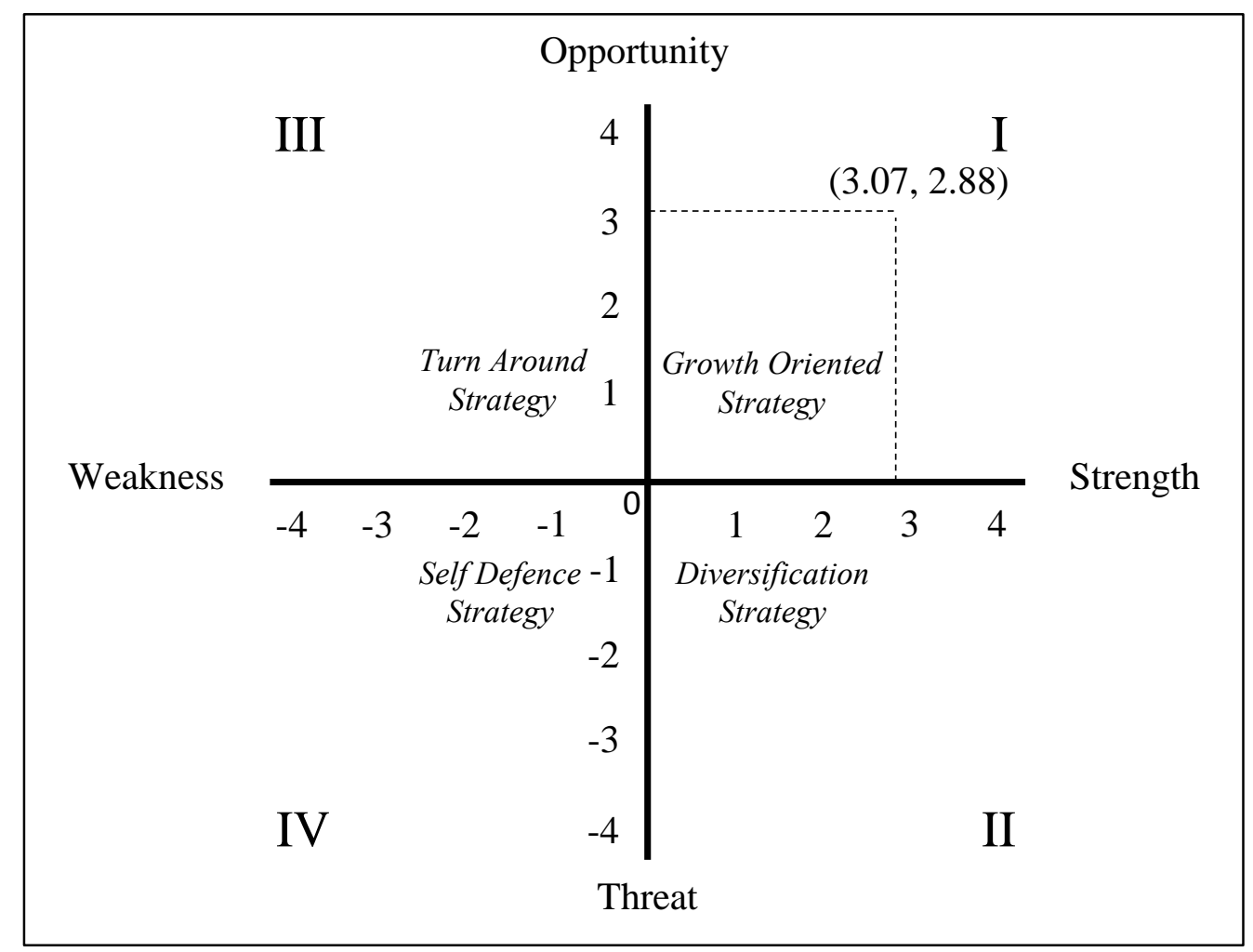

Figure 2. SWOT Quadrant of Bajomulyo Coastal Fishing Harbor Development Strategy 
Bajomulyo Coastal Fishing Harbor development strategy priority is the last stage of a series of strategies formulation analysis, namely by determining the relative attractiveness of feasible alternative strategies from the SWOT matrix, IFE matrix, and EFE matrix. Determination of the relative attractiveness of several alternative strategies using the Quantitative Strategic Planning Management (QSPM) analysis technique, which is poured into a questionnaire to competent experts in the field of Bajomulyo Coastal Fishing Harbor management. Based on the data processing, QSPM analysis results were obtained for 9 (nine) types of Bajomulyo Coastal Fishing Harbor development strategies as listed in Table 3.

\subsection{Discussion}

The results of the IFE matrix analysis (Table 1) above show that for the assessment of the strength factors get a score of 2.481, and for the weakness factors get a score of 0.587. This showed that the strength score owned by Bajomulyo Coastal Fishing Harbor is greater than the weakness that exists in Bajomulyo Coastal Fishing Harbor. Internal factors of the Bajomulyo Coastal Fishing Harbor in the development of the Bajomulyo Coastal Fishing Harbor fishing port can be implemented by utilizing existing strengths, along with minimizing the existing weaknesses.

The total value of the IFE matrix weighted score was 3.068. The magnitude of this value showed that overall the internal factors of the Bajomulyo Coastal Fishing Harbor were strong enough to support the development of the Bajomulyo Coastal Fishing Harbor fishing port. The biggest strength factor was the number of vessels that ship fish at Bajomulyo Coastal Fishing Harbor, with a weighted score of 0.611 , while the highest weakness factor was the access to and out of ships far, narrow and shallow, with a weighted score of 0.153 . This showed that the large number of vessels that ship fish in the Bajomulyo Coastal Fishing Harbor was the most influential force factor in the development of the Bajomulyo Coastal Fishing Harbor, while the access to and out of ships to distant, narrow and shallow ports was the strongest weakness factor in the Bajomulyo Coastal Fishing Harbor development.

The results of the EFE matrix analysis (Table 2) above indicate that for the assessment of the opportunity factors get a score of 2.347 , and for the threat factors get a score of 0.531. This showed that the opportunity score of the Bajomulyo Coastal Fishing Harbor was greater than the threat posed by the Bajomulyo Coastal Fishing Harbor. External factors of the Bajomulyo Coastal Fishing Harbor in the development of the Bajomulyo Coastal Fishing Harbor fishing port can be implemented by utilizing the available opportunities, accompanied by minimizing the existing threats.

The total value of the EFE weighted matrix score was 2.878. The magnitude of this value indicates that overall the external factors of the Bajomulyo Coastal Fishing Harbor have enough opportunity to support the development of the Bajomulyo Coastal Fishing Harbor fishing port. The biggest opportunity factor was the creation of Bajomulyo Coastal Fishing Harbor as one of the mina politan areas and the number of catch buyers (competition for healthy auction prices), with each score weighing 0.581 , 
while the highest threat factor is mooring facilities which are mostly managed by the community, with a weighted score of 0.161 . This showed that the creation of the Bajomulyo Coastal Fishing Harbor as one of the mina politan areas and the large number of catch buyers (healthy auction price competition) was the most influential opportunity factor in developing Bajomulyo Coastal Fishing Harbor, while the many mooring facilities managed by the community are the strongest threat factors in development Bajomulyo Coastal Fishing Harbor.

Based on the results of the IFE (Table 1) and EFE (Table 2) matrix analysis, it can be seen that the internal and external positions of the Bajomulyo Coastal Fishing Harbor development strategy were in quadrant I $(3.07,2.88)$, which was presented in Figure 2. SO (Strength - Opportunity), was a very favourable situation for the Bajomulyo Coastal Fishing Harbor development strategy. This strategy was made by utilizing all the strengths and opportunities as much as possible, by minimizing threats and weaknesses in the Bajomulyo Coastal Fishing Harbor development effort.

If in the SWOT quadrant, the internal and external positions were in quadrant $\mathrm{I}$, then the strategy was aggressive (Growth-Oriented Strategy) ${ }^{[21]}$. With the implementation of this strategy, the port manager was expected to improve the quality and quantity of the manager's human resources, as well as increase activities through improving existing systems that support the Bajomulyo Coastal Fishing Harbor management policy by increasing the application of management functions to the Bajomulyo Coastal Fishing Harbor organizing and controlling functions. Facilities that were considered vital and very important for their existence also need to be added or improved to improve the quality of services to users of the Bajomulyo Coastal Fishing Harbor services.

From Table 3 above, we can see the priority order of the nine Bajomulyo Coastal Fishing Harbor development strategies. The choice of the main strategy that was rated the most highly by experts was the S-T3 strategy, namely the implementation of the mandate of Law 23/2014 on local government. The strategy has the highest total number of attractiveness (Sum Total Attractive Score-STAS) of 7.536. Implementation of the mandate of Law No. 23 of 2014 concerning the local government was expected to be implemented immediately, to support the management and development activities in the Bajomulyo Coastal Fishing Harbor.

The next sequence was the type of W-T1 strategy, namely the determination of WKOPP and local regulations on Coastal Fishing Harbor management, with a STAS value of 7.487. For the fishing port to have full authority in the management and guarantee of its activities, the boundaries of the working area and the operational area of the fishing port were determined, based on the master plan that has been established for the benefit of the fishing port operation (Minister of Maritime Affairs and Fisheries Regulation No. 08 of 2012), and Perda on Coastal Fishing Harbor management to further clarify legal regulations and authorities between agencies related to Coastal Fishing Harbor management.

The W-T2 strategy ranks third, namely the optimization of Coastal Fishing Harbor function and performance, with a STAS value of 7.182. The strategy was implemented 
by improving integrated management in providing excellent services to service users, to provide satisfaction to service users for the services and functions of Coastal Fishing Harbor provided. Implementation of optimal Coastal Fishing Harbor functions and performance will affect the level of user satisfaction, namely fishermen ${ }^{[22]}$.

The fourth priority strategy sequence was the type of W-O2 strategy, namely the addition of manager human resources, Coastal Fishing Harbor management training to improve services to Coastal Fishing Harbor functions and facilities, as well as the addition of basic facilities, with a STAS value of 7.003. The strategy was carried out to adjust the standard number of competent Bajomulyo Coastal Fishing Harbor management personnel, who were in the area of capture fisheries and all aspects of ports. Adjusting the quality of HR management through education and training on fisheries port management, as well as adding basic facilities at Bajomulyo Coastal Fishing Harbor, including mooring dock facilities and port ponds. The facility has not been able to accommodate port activities due to the large size of GT ships and a large number of ships landing fish in Bajomulyo Coastal Fishing Harbor. It takes the construction of a mooring pier (supply pier), and a special port pond to serve ships entering the Bajomulyo Coastal Fishing Harbor. Some port facilities also need to be added to buildings and routine maintenance.

The fifth priority strategy was the type of S-O strategy, which is to build good relations with local governments, investors and relevant stakeholders to support integrated fisheries port management, with a STAS value of 6.845 . The strategy aims to unite perceptions in formulating a vision for the future regarding Bajomulyo Coastal Fishing Harbor management together between all parties, including port managers, related agencies, investors, and stakeholders. The estuary was integrated port management so that it was expected to provide increased economic growth and prosper the users of Bajomulyo Coastal Fishing Harbor services.

The sixth priority strategy was the W-O1 type of strategy, which is to improve coordination with the relevant agencies through joint agreements on port management and WKOPP submission, with a STAS value of 6.671. The strategy was carried out to realize port management so that it is more optimal, integrated and harmonious coordination between the Pati Regency Government and the Government of Central Java Province in determining the legal basis and authority of the agency towards managing the ports together in the form of mutual agreement. With a mutual agreement, WKOPP can be submitted so that the fishing port has full authority in managing and guaranteeing the fishery activities in its area.

The type of S-T2 strategy was in the seventh priority order, namely the optimization of the function of fishermen cooperatives, with a STAS value of 6.528. The strategy was carried out to maximize the function of fishermen cooperatives by submitting an increase in fuel stock in Bajamulyo Coastal Fishing Harbor solar packed fishing dealer (SPDN) to the public fueling station (SPBU) unit. Another goal was to provide easy venture capital loans with soft interest to the basket, in collaboration with financial institutions, so that in the fish auction payment at Fish Auction to fishermen, they can directly cash. 
Furthermore, the eighth priority strategy was the W-O3 strategy type, which is an alternative Coastal Fishing Harbor relocation offshore (Silugonggo River estuary), with a STAS value of 6.455 . The priority of the strategy is needed because of several problems faced by the Bajomulyo Coastal Fishing Harbor, including in and out access to the Bajomulyo Coastal Fishing Harbor ship through the Silugonggo River as far as $5.8 \mathrm{~km}$ from the river mouth, silting, and narrow ship traffic. The area of land owned by the Bajomulyo Coastal Fishing Harbor is also narrow based on the Minister of Maritime Affairs and Fisheries Regulation No. PER.8 / MEN / 2012 concerning Port Fisheries. The facilities in the Fish Auction Bajomulyo units I and II have been fully built with various facilities so that no further development can be carried out on the land.

The most recent strategy priority sequence was the S-T1 type of strategy, namely the socialization of fisheries port regulations, with a STAS value of 6.467. The strategy was carried out to provide information on legal regulations concerning port management to port service users and related stakeholders, to understand the role and function of the Bajomulyo Coastal Fishing Harbor manager. The expected outcome is the emergence of awareness and community participation in supporting good fisheries port management.

\section{CONCLUSION}

According to the results of the SWOT-QSPM analysis obtained 9 alternative Coastal Fishing Harbor management in Pati Regency, in order of priority: (1) implementation of the mandate of Law 23/2014 on local government (7.536); (2) stipulation of WKOPP and regional regulations on Coastal Fishing Harbor management (7.487); (3) optimization of Coastal Fishing Harbor function and performance implementation (7.182); (4) addition of managerial HR, Training for Coastal Fishing Harbor management in the context of improving services to Coastal Fishing Harbor functions and facilities and adding basic facilities (7.003); (5) fostering good relations with local governments, investors and relevant stakeholders to support integrated fisheries port management (6.845); (6) increase coordination with related agencies through joint agreements on port management and WKOPP submission (6.671); (7) optimization of the function of fishing cooperatives (6.528); (8) socialization of fisheries port regulations (6.467); and (9) alternative Coastal Fishing Harbor relocation offshore (Silugonggo River estuary) (6.455).

\section{ACKNOWLEDGEMENT}

Acknowledgment were addressed to lecturers and the entire academic community of the Faculty of Fisheries and Marine Sciences of Diponegoro University Semarang, Pati Regency Marine and Fisheries, Bajomulyo Coastal Fishing Harbor management in Pati Regency, and who have contributed to completing this research and writing. 


\section{REFERENCES}

[1] Wijayanto, D., Sardiyatmo, Setiyanto, I., and Kurohman, F, 2018, "Perikanan Artisanal dan Perikanan Industri Kabupaten Pati: Analisis Bioekonomi Dampak Pelarangan Cantrang", Cetakan Pertaman : Desember 2018, Penerbit : Undip Press, Semarang.

[2] Syahputra, F., Pane, A. B., Lubis, E., and Iskandar, B. H., 2015, "Kebutuhan Fasilitas Pokok Pelabuhan Perikanan Pantai Lampulo 15 Tahun Mendatang" Marine Fisheries, 6(1), pp. 33-43.

[3] Lubis, E., 2012, "Pelabuhan Perikanan", Cetakan Pertama Januari 2012. PT Penerbit IPB Press Kampus IPB Taman Kencana, Bogor, pp. 1-197.

[4] Widayati, T., 2008, "Analisis Efisiensi Teknis Tempat Pelelangan Ikan dan Tingkat Keberdayaan Pengelola Tempat Pelelangan Ikan Serta Strategi Pemberdayaannya di Wilayah Pantai Utara Jawa Tengah", Tesis Program Studi Magister Ilmu Ekonomi Dan Studi Pembangunan. Program Pasca Sarjana Universitas Diponegoro Semarang, pp. 1-192.

[5] Alfons, J. M., Tupamahu, A., and Abrahamsz, J., 2018, "Evaluasi Peran dan Strategi Pengelolaan Pangkalan Pendaratan Ikan Erie di Kota Ambon”, Jurnal Triton, 14(2), pp. 66-75.

[6] Haro, T. B. S., Surbakti, S. Br., and Nurhasanah, 2014, "Kajian Peran dan Strategi Pengelolaan Pangkalan Pendaratan Ikan Hamadi Role (Analysis and Management Strategy of Hamadi Fishing Port)", Jurnal Manajemen Perikanan dan Kelautan, 1(1), pp. 1-14.

[7] Supratikta, H., and Rusilowati, U., 2016, "Analysis Strategy Management and Development of Ocean Fishing Ports Nizam Zachman North Jakarta", International Journal of Applied Business and Economic Research, 14(13), pp. 9343-9358.

[8] Sabana, C., Madusari, B. D., and Pratikwo, S., 2016, "Kajian Strategi Pengembangan Tempat Pelelangan Ikan (FISH AUCTION) Kota Pekalongan", Dewan Riset Daerah Kota Pekalongan. Jurnal Litbang Kota Pekalongan, 11(11), pp. $117-131$.

[9] Gandara, G. A. N., Wibowo, B. A., and Triarso, I., 2016, “Analisis Tingkat Pemanfaatan dan Kebutuhan Fasilitas Fungsional Pelabuhan Perikanan Pantai (COASTAL FISHING HARBOR) Bajomulyo Pati”, Jawa Tengah. Journal of Fisheries Resources Utilization Management and Technology, 5(4), pp. 123-132.

[10] Pamungkas, I., 2017, "Model Pengembangan Pelabuhan Perikanan pantai (COASTAL FISHING HARBOR) Berbasis Pelabuhan Higienis : Studi Kasus Pelabuhan Perikanan Pantai Bajomulyo", Institut Teknologi Sepuluh Nopember, (http:repository.its.ac.id/id/eprint/3916).

[11] Murwati, T., 2010, "Kajian Pengaruh Aktivitas Pelabuhan Perikanan Terhadap Aspek Kualitas Air Sungai Juwana dan Persepsi Masyarakat (Studi Kasus di Pelabuhan Perikanan Pantai (COASTAL FISHING HARBOR) Bajomulyo, Kecamatan Juwana, Kabupaten Pati)", Tesis Program Magister Ilmu Lingkungan. Program Pascasarjana Universitas Diponegoro, Semarang. 
[12] Ikasari, A. C., 2017, "Konsep Kebijakan Alih Kelola Pelabuhan Perikanan di Jawa Barat", Jurnal Ilmiah Magister Ilmu Administrasi (JIMIA), 11(2), pp. 4455.

[13] [DKP] Dinas Kelautan dan Perikanan Provinsi Jawa Tengah, 2013, "Penyusunan Masterplan (Rencana Induk) Zona Inti dan Detail Engineering Design (DED) Pelabuhan Perikanan Pantai Bajomulyo Pati".

[14] Falatehan, A. F., 2016, "Analytical Hierarchy Process (AHP) Teknik Pengambilan Keputusan untuk Pembangunan Daerah", Indomedia Pustaka, Yogyakarta, pp. 1-102.

[15] David, F. R., 2011, "Strategic Management (Concepts and Cases)", Pearson Education, Inc., publishing as Prentice Hall, One Lake Street, Upper Saddle River, New Jersey, ISBN-13:9780136120988.

[16] Winarsita, N., Wijayanto, D., and Setiyanto, I., 2015, "Analisis Teknis dan Ekonomis Kapal Purse Seine Berpendingin Freezer dan ES di Pelabuhan Perikanan Pantai (COASTAL FISHING HARBOR) Bajomulyo Kecamatan Juwana, Kabupaten Pati", Journal of Fisheries Resources Utilization Management and Technology, 3(3), pp. 32-40.

[17] Setiawan, H., Pane, A. B., and Lubis, E., 2019, "Strategi Pengembangan Pelabuhan Perikanan Pantai Bajomulyo untuk Meningkatkan Fungsi Pelabuhan Perikanan", Albacore, 3(1), pp.59-72.

[18] [KKP] Kementerian Kelautan dan Perikanan, 2012, "Peraturan Menteri Kelautan dan Perikanan Republik Indonesia Nomor PER.08/MEN/2012 tentang Kepelabuhanan Perikanan", Jakarta (ID), KKP.

[19] [KKP] Kementerian Kelautan dan Perikanan, 2017, "Keputusan Menteri Kelautan dan Perikanan Republik Indonesia Nomor 50/KEPMEN-KP/2017 tentang Estimasi Potensi, Total Tangkapan yang Diperbolehkan, dan Tingkat Pemanfaatan Sumberdaya Ikan di WPPNRI", Jakarta (ID), KKP.

[20] [KKP] Kementerian Kelautan dan Perikanan, 2016, "Peraturan Menteri Kelautan dan Perikanan Republik Indonesia Nomor 71/PERMEN-KP/2016 Tentang Jalur Penangkapan Ikan dan Penempatan Alat Penangkap Ikan di WPPNRI", Jakarta (ID), KKP.

[21] Rangkuti, F., 2014, "Teknik Membedah Kasus Bisnis: Analisis SWOT (Cara Perhitungan Weight, Rating, dan OCAI)", Ed.18, PT. Gramedia Pustaka Utama, Jakarta, pp. 1-246.

[22] Nurhayatin, O. T., Mudzakir, A. K., and Wibowo, B. A., 2016, “Analisis Tingkat Kepuasan Nelayan terhadap Pelayanan Penyediaan Kebutuhan Melaut di Pelabuhan Perikanan Nusantara (PPN) Prigi Kabupaten Trenggalek, Jawa Timur", Journal of Fisheries Resources Utilization Management and Technology, 5(1), pp. 19-27. 